\title{
Information Quality under IFRS, IFRS for SME and German-GAAP-Survey on Preferences of Non-Publicly Traded Mid-Sized Corporations
}

\author{
Markus Kreipl'1, Timm Hane'2, Stefan Mueller ${ }^{1}$ \\ ${ }^{1}$ Department for Accounting and Auditing, Helmut-Schmidt-University, Hamburg, Germany \\ ${ }^{2}$ Senger Holding $\mathrm{GmbH}$, Rheine, Germany \\ Email: kreipl@hsu-hh.de, timm.hane@auto-senger.de, smueller@hsu-hh.de
}

Received 5 February 2014; revised 5 March 2014; accepted 11 April 2014

Copyright ( 2014 by authors and Scientific Research Publishing Inc.

This work is licensed under the Creative Commons Attribution International License (CC BY). http://creativecommons.org/licenses/by/4.0/

(c) (i) Open Access

\begin{abstract}
The paper provides survey data on the information quality under IFRS, IFRS for SME and GermanGAAP from the perspective of non-publicly traded mid-sized corporations. Survey findings suggest for a higher quality of financial statements under German-GAAP compared to those under IFRS. Beyond that, more corporations anticipate an increase in information quality with a shift from (full-)IFRS to IFRS for SME. The findings of empirical research previously obtained regarding publicly traded corporations, which show preferences for IFRS, cannot be confirmed in respect of the preferences of the non-publicly traded mid-sized corporations participating. This may be due to a general skepticism towards IFRS, a lack of IFRS knowledge, the convergence of German-GAAP and IFRS owing to the German Accounting Law Reform Act or in-group biases.
\end{abstract}

\section{Keywords}

IFRS, IFRS for SME; German-GAAP; Information Quality; Non-Publicly Traded; Mid-Sized Corporations

\section{Introduction}

German legislature is engaged in competition for favorable accounting standards with the IASB by launching the Accounting Law Reform Act in 2009. So currently, separate financial statements under IFRS are still only permitted as a complement to those prepared under German-GAAP and their implementation is limited to (full-) 
IFRS. Consolidated financial statements of publicly traded corporations, however, already have to be prepared under (full-)IFRS and are voluntary for other corporations. Thereby, a stock exchange listing does not necessarily result in public trading and public trading is not limited to Inc. Only Inc. traded at an organized/regulated market within the European Union, or those who have applied for an approval in such a market are defined as being publicly traded according to German-GAAP [1] and European Accounting Directives. Furthermore, all kinds of corporations with transferable securities (with the exception of payment instruments) registered in such a market are defined as being publicly traded.

Researchers, politicians, auditors and entrepreneurs have argued for years, whether Germany, respectively the European Union should adopt IFRS for separate financial statements or not. Additionally for both separate, and consolidated financial statements, it is widely discussed whether IFRS for SME may be an additional option.

There is broad empirical evidence on the quality of information on various accounting systems from the perspective of publicly traded corporations. Due to the lack of data for non-publicly traded corporations, findings regarding the quality of accounting data of those entities are rare. Although the transmission of results about the information quality of financial statements or standards regarding publicly traded corporations seems possible in general, there is no evidence for such alienability. Therefore, this paper examines information quality under German-GAAP, (full-)IFRS and IFRS for SME from the perspective of non-publicly traded mid-sized corporations. Our findings are based on a survey of chief executive officers and commercial directors.

Within the context of publicly traded corporations, it was assumed that (consolidated) financial statements under German-GAAP are less relevant/useful or of less information content/quality than those prepared in accordance with IFRS or US-GAAP. Prior research sustains this assumption (see Section 2.3). Because of this, German legislature intended to equal relevance/usefulness of German-GAAP to IFRS but deliver a simpler and cheaper alternative [2]. Therefore, various accounting options have been deleted; accounting bans have been abolished and accounting methods have been changed. Although there is now a much smaller gap between the different accounting standards due to the German Accounting Law Reform Act in 2009, there still seem to be differences regarding the level of relevance/usefulness respectively information quality [3]. However, we expect the findings from our survey regarding non-publicly traded mid-sized corporations to differ from prior research gained from data concerning publicly traded corporations, as we anticipate a much lower approval for IFRS statements within the group of non-publicly traded mid-sized corporations.

Against the backdrop of a possible IFRS adoption for separate financial statements and considerations about an application of IFRS for SME, the findings appear to be of particular interest, as most corporations in Germany aren't publicly traded-there are 632, 399 corporations and 3,620, 576 companies in Germany in total [4], whereas only $512(0.0810 \% / 0.014 \%)$ are publicly traded at Deutsche Boerse [5] [6]; overall there are only approximately 1000 publicly traded corporations in Germany of which only 612 are obliged to apply to IFRS [7].

The findings from our survey suggest for a relatively higher preference of non-publicly traded mid-sized corporations for German-GAAP and that IFRS for SME will lead to improvements compared to (full-)IFRS. As prior research mainly rejects an IFRS for SME adoption, these findings are unexpected.

\section{Literature Review}

\subsection{Actual and Potential IFRS Reporting in Germany}

First, regardless of the legal form, German-GAAP provides for the preparation of separate financial statements under German-GAAP, including the balance sheet and the profit \& loss statement. Only sole traders are exempted from the preparation under certain circumstances. Second, corporations are obliged to extend separate financial statements by notes and have to comply with additional/different accounting regulations, whereby corporations of minimal size (corporations of minimal size do not exceed 2 of the following 3 criteria on 2 reporting dates in a row: EUR 350,000 total assets, EUR 700,000 net revenues and an annual average of ten employees) are not obliged to prepare notes on condition of additional disclosures under the balance sheet. For publicly traded corporations not obligated to prepare a consolidated financial statement it is also foreseen to obligingly include a cash flow statement and a statement of changes in equity. Segment reporting is voluntary for those. The supplementary provisions thereby exempt subsidiaries included in a consolidated financial statement of a corporate parent based in Germany.

Until 1998 German corporations had to prepare consolidated financial statements under German-GAAP-IFRS or US-GAAP statements could only be prepared in addition. The legislature then responded to a stronger align- 
ment of (consolidated) accounting data to its information objective. The KapAEG Act 1998 [8], effective until December 2004, then allowed publicly traded corporations to prepare consolidated financial statements under IFRS or US-GAAP instead of German-GAAP. The BilReG Act 2004 [9], effective since 2005, afterwards implemented the obligation for publicly traded parent corporations to prepare consolidated financial statements according to IFRS. Nevertheless, IFRS accounting in those cases is limited to the standards adopted for application in the European Union. It is negligible whether the parent corporation is a subsidiary again [10]. Non-publicly traded parent corporations are since then allowed for group accounting under IFRS.

The adoption of IFRS for SME is widely discussed (see Section 2.3), but not designated to date in both the European Union and Germany.

\subsection{Information Quality—Criteria Definition}

In empirical research regarding publicly traded corporations, the objective of determining the information content is superior to the objective of determining decision relevance, value relevance and/or decision usefulness of accounting data [11]. Deviant, numerous publications focus on information quality as the superior concept. Beside decision or value relevance, asymmetric information is often used as a determinant of information quality. However, some do so vice versa. They define information quality as determinant of information asymmetry. Beside this, many studies define "own" determinants or use the terms without further definition or subdivision [12]-[17]. Thus, a standard definition for both, information quality and information content is not available.

Nevertheless, most empirical studies define the degree of ascendancies of company-specific information (e.g. in terms of separate and consolidated financial statements) on stock prices or trading volumes in temporal relation to their publication as a measure for information quality/content of accounting data [18]. Accordingly, accounting data has information quality/content, if the data directly or indirectly affects market pricing, interest yields or trading volumes. However, throughout accounting history research accrued that defines management and auditors incentives, the level of investor protection and the efficiency of the judiciary in a country as a measure for information quality/content [12]-[17].

Naturally, the influence of company-specific information on market pricing, interest yields or trading volumes in temporal relation to their publication, using decision or value relevance studies, largely cannot be determined for non-publicly traded (mid-sized) corporations. Therefore, we based our study on a survey and the fulfillment of 3 criteria identified as quality driving factors. The criteria were derived from the accounting objectives under German-GAAP, as the systematic within an accounting system is of central importance for the quality of accounting data and researchers justifiably criticize that empirical studies usually do not take accounting objectives into account [19].

Whilst separate financial statement preparation under German-GAAP follows a multi-purpose approach, Anglo-American/Anglo-Saxon accounting systems primarily succeed the objective of providing information. Furthermore and unlike continental European accounting standards, which zero in on a wide range of potential users, Anglo-American/Anglo-Saxon accounting systems follow the objective of providing financial information that is useful to a single group or a limited number of users [20], e.g., IFRS focus on existing and potential investors, lenders and other creditors [21]. US-GAAP does so regarding present and potential investors, creditors and other (external) users [22].

Contemplating separate financial statements under German-GAAP, the stated multi-purpose approach follows from commercial, corporate and tax laws as well as criminal law standards. The legal obligation to keep records implemented in article 238, section 1 German-GAAP allows for the deduction of three accounting objectives: documentation, accountability and information. Accountability can additionally be derived from article 242, section 1 and article 264, section 2 German-GAAP. Documentation is furthermore substantiated by the articles 283 and 283b German-Criminal Code. Profit/dividend assessment is, with respect to the legal form, set in the articles 58 and 150 German-Stock Corporation Act and the articles 29 and 30 German-Limited Liability Companies Act, ensuring an appropriate profit/dividend distribution in the context of shareholder protection and a dividend barrier on behalf of a company's creditors. As profit assessment for tax purposes is based on ascertainment of profits under German-GAAP according to Article 5, Section 1 German-Income Tax Act, profit/dividend assessment under German-GAAP does also suit as a tax base. Overall, there are three main objectives, which can be divided into two subcategories each. For an overview see Table 1.

Ensuing, the following criteria (the survey was conducted in German and translated for this paper) were clas- 
Table 1. Accounting objectives under German-GAAP.

\begin{tabular}{cc}
\hline & Accounting objectives under German-GAAP \\
\hline Documentation & legal obligation to keep records \\
& as evidence \\
Profit/dividend assessment & dividend assessment \\
Information & profit assessment for tax reasons \\
& information (external) \\
& accountability (internal) \\
\hline
\end{tabular}

sified as influencing quality:

- Corporate management;

- Dividend assessment;

- Decision usefulness.

Corporate management thereby covers the objective to document all business transactions and to give account to the company. Dividend assessment is beside profit assessment for tax reasons one of the two subcategories of the objective to assess profits/dividends-tax assessment was neglected, as IFRS and IFRS for SME are detached from tax accounting. Decision usefulness covers the information objective (external).

\subsection{Prior research}

According to broad empirical evidence, financial statements in general have information quality, as for example Ball/Brown [23], Beaver [24], Beaver/Lambert/Morse [25], Lev [26], Hayn [27], Amir/Lev [28], Collins/Maydew/Weiss [29], Ely/Waymire [30], Lev/Zarowin [31] and Brown/Lo/Lys [32] have proven decades ago.

Financial statements prepared under (full-)IFRS are expected to show a relatively higher level of information quality than those prepared under German-GAAP or other conservative-mostly continental European-GAAP. This prediction is mostly supported by prior research. For example, Armstrong/Barth/Jagolinzer/Riedl find that the adoption of IFRS in Europe has led to positive market reactions, indicating to a higher level of relevance [33]. Based on Beaver's paper [24], Landsman/Maydew/Thornock prove a relatively higher level of decision relevance of accounting data in countries that duly adopted IFRS [34]. Similarly, Bartov/Goldberg/Kim find that the (relative) value relevance using both, US-GAAP and IFRS as well as the level of relevance resulting from a shift to US-GAAP or IFRS is higher than under German-GAAP [35]. Barth/Landsman/Lang/Williams as well as Hung/Subramanyam confirm these findings regarding the comparison of relevance levels under IFRS and German-GAAP, whereas Hung/Subramanyam additionally obtained familiar findings concerning US-GAAP and German-GAAP [36] [37]. Gassen/Sellhorn find that voluntary application of IFRS, i.e. IFRS earnings announcements, led to a higher quality and lower information inefficiencies [38]. However, e.g. Wang/Yu could not approve these findings. According to their results, accounting data under IFRS and/or US-GAAP isn't more relevant than accounting data prepared in accordance with local GAAP [18]. In contrast to his assumptions, Schiebel found a higher level of value relevance for financial statements under German-GAAP than for those prepared under IFRS [39]. Although there are contrary findings, in all IFRS are proven to be of a higher information quality than German-GAAP from the perspective of publicly traded corporations (see the meta-study by Kreipl for a more comprehensive overview [3]). The reasons for that gap in information quality vary. Beside a shift in financial reporting transparency e.g. a reduction of information asymmetries or the more market oriented approach of IFRS may be responsible on that account.

Albeit, empirical studies concerning decision and value relevance as well as information quality are suffering from several weaknesses that need to be considered. Decision relevance studies and researches regarding information quality based on those studies are connected to woes owing to over-reaction or under-reaction of market participants on new (accounting) information [40]-[42]. Above, the announcement of new information usually causes lagged price changes beyond fundamentally justified measures [43]. Mean reversion also raises such bias, as stock prices tend to be cyclical and move to the average price over time [42] [44] [45]. Furthermore, smaller corporations typically have higher yields than companies with correspondingly large capitalization [46]-[48] and 
stock yields vary subject to the calendar period or weekdays [49]. Beyond this, stock yields are positively linked with the market-to-book ratio [46] [50] and negatively linked with the price-earnings ratio [51]. The configuration of the Ohlson model is in conflict with existing accounting systems [52]-[54]. Beside research design specific issues, corresponding studies succumb to the restrictions of the assumptions made. Thereby, assumptions concerning information efficiency and rational choice are of importance in particular [53] [55]-[57]. The thesis of existing market efficiency prompted by empirical research in the past (e.g. Ball/Brown [23] and Beaver [24]) has been relativized by new investigations (e.g. Kothari [58]; Wagenhofer/Ewert [53]). Concerning rational choice, several studies suggest that this hypothesis is untenable (e.g. Hoitash/Krishnan/Sankaraguruswamy [59]). Furthermore, the use of R2 negatively affects the validity of findings, whereby R2-related distortions can sometimes be adjusted [60]-[65]; with a comprehensive discussion on the adjustment options [66]. OLS related assumptions of homoscedasticity and non-existing autocorrelation of the error terms that are not durable at a price modeling (based on unscaled data). Granger/Newbold [67], Easton [68], Easton/Sommers [64] und Philipps [69] found that price modeling causes homoscedasticity or autocorrelation. Beside this, price modeling is negatively affected by scale effects [70]; with corresponding empirical results e.g. [32]. Yield modeling leads to biases due to the accounting recognition lag [71]-[73] (with corresponding empirical results e.g. Easton/Harris/Ohlson [74]) and transitory earnings [71]. Thus, e.g. Hayn [32] and Basu [75] found that the coefficient of determination is determined by the positivity of accounting information. Holthausen/Watts [19] comprehensively criticize that literature/empirical studies concerning relevance respectively information quality omitted to develop a descriptive theory concerning financial reporting and standard-setting and that the conclusions therefore aren't valid.

The possible adoption of IFRS for SME in the European Union and especially in Germany is controversially discussed. Jessen/Haaker state, that mid-tier companies mutually refuse a shift from German-GAAP to IFRS for SME [76]. They consider it as proven, theoretically and empirically, that accounting convergence within the European Union based on an IFRS for SME adoption is both, useless and impossible [76]. Connected to the reproach of unreflective consideration by other researchers, Jessen/Haaker [76] argue that IFRS for SME would sure be associated with additional costs whilst advantages are uncertain [76]. Beside others, this should result from a higher volatility (likewise [77]) and a less compelling dividend barrier (likewise [78]). Janssen/Gronewold [79], Kirsch [80] and Schildbach [81] also reject an IFRS for SME adoption. Eierle/Haller [82] on the other hand quote a high degree of acceptance in numerous countries (the standard is inter alia mandatory or optional applicable in South Africa, Brazil, the Philippines, Hong Kong, Tanzania, Sierra Leone, Costa Rica, Namibia, Nigeria and Mauritius [83]) around the world. Referring to a summary report on IFRS for SME by the European Commission [84], they furthermore state that 13 European countries (Great Britain, Denmark, Spain, Sweden, Czech Republic, Poland, Cyprus, Greece, Ireland, Malta, Estonia, Portugal, Netherlands) recommend an adoption whilst only 8 do not [82]. Although publicly traded corporations aren't allowed to use the IFRS for SME according to the IASB (Section 1.2 IFRS for SME), Eierle/Haller [82] furthermore carried out a survey on the assessment regarding the usefulness of IFRS for SME for small (revenues $<€ 130 \mathrm{M}$ ) publicly traded corporations in Germany, as national standard setters can vary the circle of preparers (BC77 IFRS for SME). Their results clearly indicate that easements resulting from IFRS for SME are for "small" publicly traded corporations related to higher benefits and lower costs [82]. Concerning non-publicly traded German companies, Eierle/Haller [85] furthermore investigate the assessment of IFRS for SME compared to German-GAAP. The survey's results are characterized by a higher degree of heterogeneity. In 6 out of 10 subcategories the participants expect higher benefits for external users in case of an IFRS for SME application. With a view to benefits for internal users, the ratio changes to 5:5. With regard to accounting costs, German-GAAP is more favorable according to their opinion [85].

\section{Data and Research Design}

\subsection{Participants}

The survey was carried out autumn 2010 for six weeks using an online questionnaire (2 ask [86]). All corporations with a valid email address, less than 250 employees and revenues exceeding $€ 10$ million in 2008 were selected from the Hoppenstedt database following to the definition of mid-sized entities provided by the European Union [87]. However, the requirements concerning size lead to a selection bias with respect to firm size. Out of the 6937 corporations written down 824 chief executive officers and commercial directors participated in the survey. This corresponds to a comparatively high return rate of $11.9 \%$, whereby only 508 questionnaires were 
fully filled out. 68 (13.39\%) corporations were publicly traded and 440 (86.61\%) were not. Survey data from publicly traded corporations are only given for information. Both groups should not be compared, as comparative results are (still) expected to be biased by information asymmetries according to the level of IFRS knowledge within both groups-beside size effects, non-publicly traded (mid-sized) corporations on average are often not as familiar with IFRS as publicly traded corporations.

\subsection{Interrogation}

As part of the survey a total of 34 aspects with several criteria each were investigated, whereas only the following 2 aspects with the following 3 criteria/subcategories each are subject to this paper.

1) Which accounting standard is more qualified for the fulfillment of the following criteria, German-GAAP or IFRS?
a) Corporate management;
b) Dividend assessment;
c) Decision usefulness.
2) In which of the following criteria will IFRS for SME lead to improvements compared to the (full-)IFRS?
a) Corporate management;
b) Dividend assessment;
c) Decision usefulness.

\subsection{Procedure}

We crossed both aspects and their subcategories with the classification as publicly traded and non-publicly traded, whereas seven-tier Likert-scales were used with $\{1\}$ "German-GAAP much better" for question 1) and "IFRS for SME much better" for question 2) via $\{2\}$ and $\{3\}$ to " $\{4\}$ pendant" and via $\{5\}$ and $\{6\}$ to $\{7\}$ "IFRS much better" for question 1) and "(full-)IFRS much better" for question 2). The scale divisions $\{1\}-\{3\}$ and $\{5\}-\{7\}$ were concentrated at the end. Furthermore, it was possible to use the field "not specified", which led to a maximum of 495 answers for question 1) and 229 for question 2).

To prove whether mean values do significantly differ among publicly-traded and non-publicly-traded corporations we performed a t-test with a significance level of 0.05 assumed. Thereby, we speak of significantly different mean values in case the null hypothesis (mean equality) has to be rejected in behalf of the alternative hypothesis $\mathrm{H} 1$ (different mean values).

\section{Analyses and Results}

\subsection{German-GAAP and (Full-)IFRS}

Regarding the question which accounting standard, German-GAAP or (full-)IFRS, is more qualified for criteria fulfillment, and therefore leads to a relatively higher level of information quality from the perspective of the survey participants, the majority of respondents was pendant across all criteria within the group of non-publicly traded mid-sized corporations-for detailed data concerning the results shown hereinafter see Table A2. The same applies to publicly traded mid-sized corporations.

In total and concerning the appraisal by non-publicly traded mid-sized corporations we found a relatively higher preference for German-GAAP over all three criteria. Within the group of publicly traded mid-sized corporations, however, more respondents expect German-GAAP to be more qualified for criteria fulfillment only referring to two criteria. As IFRS are unlike bank orientated continental European GAAP considered to be market orientated (e.g. Ali/Hwang [88]; Guenther/Young [89]), it is hardly surprising that publicly traded mid-sized corporations have in total relatively lower preferences for German-GAAP than non-publicly traded mid-sized corporations. Indeed, it is surprising that a higher proportion prefers German-GAAP over IFRS concerning two out of three criteria within this group. Based on the pendant majority and ensuing from an equal weighting of the three criteria, concerning the preferences of those respondents not pendant, we cannot confirm prior research in respect of publicly traded corporations. Furthermore we found evidence that non-publicly traded mid-sized corporations prefer German-GAAP over IFRS with an even sharper distinction. As follows, we focus on the preferences of those respondents not pendant.

Whilst more non-publicly traded mid-sized corporations are in favor of German-GAAP with regards to their 
ability for corporate management (criteria 1.a), the results from the group of publicly traded mid-sized corporations are less appreciable. The arithmetic mean value is 3.46 with a standard deviation of 1.37 for non-publicly traded mid-sized corporations and 3.87 with a standard deviation of 1.48 for publicly traded mid-sized corporations, whereas the mean values do differ significantly.

In respect of dividend assessment (criteria 1.b), findings are closely similar but-as expected (according to prevailing opinion in Germany IFRS aren't suitable for dividend assessment [90]-[96])—more obvious. 36.30\% of the non-publicly traded mid-sized corporations prefer German-GAAP and only 8.67\% expect IFRS to be more qualified for criteria fulfillment. Survey data concerning publicly traded mid-sized corporations show that $39.71 \%$ consider German-GAAP to be more suited whilst only $8.82 \%$ do so pertaining IFRS. The arithmetic mean value is 3.33 with a standard deviation of 1.33 for non-publicly traded mid-sized corporations and 3.29 with a standard deviation of 1.36 within the group of publicly traded mid-sized corporations, whereas the mean values do not differ significantly.

Different to the findings concerning the first two criteria, survey data show that more respondents from the group of non-publicly traded mid-sized corporations expect German-GAAP to be of relatively higher decision usefulness (criteria 1.c), whereas the majority of non-pendant publicly traded mid-sized corporations does so for IFRS-based accounting data/information. The arithmetic mean value is 3.71 with a standard deviation of 1.20 for non-publicly traded corporations and 4.01 with a standard deviation of 1.32 within the group of publicly traded mid-sized corporations, whereas the mean values do not differ significantly.

\subsection{IFRS for SME Versus (Full-)IFRS}

Analogously to the question whether German-GAAP or IFRS leads to a relatively higher level of information quality from the perspective of the survey participants, the majority was pendant across all criteria concerning the question either IFRS for SME would result in a higher level of information quality compared to (full-)IFRS within the group of non-publicly traded and publicly traded mid-sized corporations-for detailed data concerning the results shown hereinafter see Table A3.

The findings suggest that a majority of those respondents not pendant expects quality improvements compared to (full-)IFRS concerning all three quality criteria, be it non-publicly traded or publicly traded mid-sized corporations. As prior research mainly rejects an IFRS for SME adoption, whereas it has to be considered limiting that they directly compare German-GAAP und IFRS for SME, these findings are unexpected.

$24.12 \%$ of the non-publicly traded mid-sized corporations expect IFRS for SME to be of higher quality than (full-)IFRS with regards to their ability for corporate management (criteria 2.a) and only 6.03\% do so vice versa. The results from the group of publicly traded mid-sized corporations are even more appreciable. $30.00 \%$ of the publicly traded mid-sized corporations prefer IFRS for SME whilst only $6.67 \%$ have a preference for (full-) IFRS. For non-publicly traded mid-sized corporations the arithmetic mean value is 3.67 with a standard deviation of 0.948 . The results from the group of publicly traded mid-sized corporations show an arithmetic mean value of 3.33 with a standard deviation of 1.348 . Thereby, the mean values do not differ significantly.

Concerning dividend assessment (criteria 2.b) findings are closely similar. Both, non-publicly and publicly traded mid-sized corporations, prefer IFRS for SME over (full-)IFRS and expect quality improvements. The arithmetic mean value is 3.74 with a standard deviation of 0.842 for non-publicly traded mid-sized corporations and 3.61 with a standard deviation of 1.066 within the group of publicly traded mid-sized corporations, whereas the mean values do not differ significantly.

In respect of decision usefulness (criteria 2.c), a majority of both, non-publicly and publicly traded mid-sized corporations, anticipates IFRS for SME to be of relatively higher quality. The arithmetic mean value is 3.74 with a standard deviation of 0.876 for non-publicly traded mid-sized corporations and 3.67 with a standard deviation of 1.322 within the group of publicly traded mid-sized corporations. The mean values do not differ significantly.

\section{Conclusions}

While the IFRS application for consolidated financial statements prepared by publicly traded corporations resulted in a common set of standards within the European Union, a variety of local accounting standards are applicable for separate financial statements and consolidated financial statements of non-publicly traded corporations. Beside conceptions for an entire IFRS adoption, the adoption of IFRS for SME is widely discussed, but not designated to date in both the European Union and Germany. Whereas there is broad empirical evidence on 
the quality of information of different accounting systems from the perspective of publicly traded corporations, findings regarding the quality of accounting data of non-publicly traded (mid-sized) corporations are rare. As it is very important to lead the discussion on a broad comprehensive data base and due to the fact that most corporations in Germany and the European Union aren't publicly traded, we consider data on accounting preferences of non-publicly traded mid-sized corporations as being essential. Against this backdrop, this paper investigates whether non-publicly traded mid-sized corporations prefer IFRS, IFRS for SME or German-GAAP concerning the information quality of accounting data.

We expected the findings from our survey to differ from prior research gained from data concerning publicly traded corporations, as we anticipated a much lower approval for IFRS statements within the group of non-publicly traded mid-sized corporations. Our expectations thereby resulted from the implementation of the GermanAccounting Law Reform Act in 2009, intended to equal relevance/quality of German-GAAP to IFRS, a general skepticism towards IFRS in Germany and potential in-group biases. Due to the controversial discussion about a possible adoption of IFRS for SME and a majority considering it as proven that accounting convergence within the European Union based on an IFRS for SME adoption is both, useless and impossible, we furthermore expected a majority of our respondents to prefer (full-)IFRS to IFRS for SME.

As expected we find indication for a relatively higher preference of non-publicly traded mid-sized corporations for German-GAAP, albeit and unexpectedly, survey data to show a pendant majority. Surprisingly, we even find a relatively higher preference for German-GAAP within the group of publicly traded mid-sized corporations.

Concerning the question, either IFRS for SME would result in a higher level of information quality compared to (full-)IFRS, findings suggest that the respondents of both groups expect IFRS for SME to be of higher quality. As prior research mainly rejects an IFRS for SME adoption, these findings are unexpected.

Overall, our findings suggest that non-publicly traded mid-sized corporations prefer German-GAAP to (full-) IFRS with respect to the level of information quality but expect benefits of an IFRS for SME adoption compared to an application of (full-)IFRS.

\section{References}

[1] German Government (2009) Article 264d German-GAAP in Conjunction with Article 2 Section 1 and 5 German-Securities Trading Act.

[2] German Government (2008) Accounting Law Reform Act-Gouvernement Draft, Gesetzentwurf der Bundesregierung_Gesetz zur Modernisierung des Bilanzrechts (Bilanzrechtsmodernisierungsgesetz—BilMoG). BT-Drs. 10/10067 and/or BR-Drs. 344/08.

[3] Kreipl, M. (2010) Die Auswirkungen des Bilanzrechtsmodernisierungsgesetzes auf die Entscheidungs-und Wertrelevanz der handelsrechtlichen Rechnungslegung. Goettingen.

[4] Destatis (2013) Unternehmensregister-Unternehmen nach zusammengefassten Rechtsformen. https://www.destatis.de/DE/ZahlenFakten/GesamtwirtschaftUmwelt/UnternehmenHandwerk/Unternehmensregister/Ta bellen/UnternehmenRechtsformenWZ2008.html

[5] Xetra (2013) Number of Stocks Listed at Deutsche Boerse. http://xetra.com/xetra/dispatch/de/listcontent/gdb_content_pool/imported_files/public_files/10_downloads

[6] Xetra (2013) Number of Bonds Listed within the Prime Standard of Deutsche Boerse. http://xetra.com/xetra/dispatch/de/kir/navigation/xetra/200_listing/500_statistics/600_es_bond_list

[7] Kueting, K. (2011) IFRS-Anwendung in Deutschland: Nur ein Papiertiger? Internationale und kapitalmarktorientierte Rechnungslegung, 11, 33-334.

[8] German Gouvernement (1998) Gesetz zur Verbesserung der Wettbewerbsfaehigkeit deutscher Konzerne an Kapitalmaerkten und zur Erleichterung der Aufnahme von Gesellschafterdarlehen (Kapitalaufnahmeerleichterungsgesetz-KapAEG). BGBl. I, 707-709.

http://www.bgbl.de/banzxaver/bgbl/start.xav?startbk=Bundesanzeiger_BGBl\&jumpTo=bgbl198s0707.pdf

[9] German Gouvernement (2004) Gesetz zur Einführung internationaler Rechnungslegungsstandards und zur Sicherung der Qualitaet der Abschlusspruefung (Bilanzrechtsreformgesetz BilReG). BGBl. I, 3166-3182. http://www.bgbl.de/banzxaver/bgbl/start.xav?startbk=Bundesanzeiger BGBl\&jumpTo=bgbl104s3166.pdf

[10] Kozikowskiand, M. and Ritter, K.M. (2010) Article 315a HGB. In: Ellrott, H., Foerschle, G., Kozikowski, M. And Winkeljohann, N., Eds., Beck'scher Bilanz Kommentar, 7th Edition, C. H. Beck, Munich, 1942-1946.

[11] Coenenberg, A.G. (2005) Jahresabschluss und Jahresabschlussanalyse. 20th Edition, Schaeffer Poeschel, Stuttgart. 
[12] Ball, R. (2001) Infrastructure Requirements for an Economically Efficient System of Public Financial Reporting and Disclosure. http://muse.jhu.edu/journals/brookings-wharton_papers_on_financial_services/v2001/2001.1ball.pdf

[13] Watts, R.L. and Zimmerman, J.L. (1986) Positive Accounting Theory. Prentice-Hall, Englewood Cliffs.

[14] Ball, R., Kothari, S.P. and Robin, A. (2000) The Effect of International Institutional Factors on Properties of Accounting Earnings. Journal of Accounting and Economics, 29, 1-51. http://dx.doi.org/10.1016/S0165-4101(00)00012-4

[15] Ball, R., Robin, A. and Wu, J.S. (2003) Incentives versus Standards: Properties of Accounting Income in Four East Asian Countries. Journal of Accounting and Economics, 36, 235-270. http://dx.doi.org/10.1016/j.jacceco.2003.10.003

[16] Leuz, C., Nanda, D. and Wysocki, P.D. (2003) Earnings Management and Investor Protection: An International Comparison. Journal of Financial Economics, 69, 505-527. http://dx.doi.org/10.1016/S0304-405X(03)00121-1

[17] Burgstahler, D.C., Hail, L. and Leuz, C. (2006) The Importance of Reporting Incentives: Earnings Management in European Private and Public Firms. The Accounting Review, 81, 983-1016. http://dx.doi.org/10.2308/accr.2006.81.5.983

[18] Wang, J.W. and Yu, W.W. (2009) The Information Content of Stock Prices, Reporting Incentives, and Accounting Standards: International Evidence. http://iaf.shufe.edu.cn/upload/ info/kjycwyjy/25264 0906100248481.pdf

[19] Holthausen, R.W. and Watts, R.L. (2001) The Relevance of the Value Relevance Literature for Financial Accounting Standard Setting. Journal of Accounting and Economics, 31, 3-75. http://dx.doi.org/10.1016/S0165-4101(01)00029-5

[20] Watrin, C. (2009) Einfuehrung in die Rechnungslegung nach IFRS—Institutioneller Rahmen und IASB. In: Hennrichs, J., Kleindiek, D. and Watrin, C., Eds., Muenchener Kommentar-Bilanzrecht_IFRS, Munich, 3-14 (introduction).

[21] IASB (2010) IFRS Conceptual Framework. IASB.

[22] FASB (2008) Statement of Financial Accounting Concepts No. 1: Objectives of Financial Reporting by Business Enterprises. FASB.

[23] Ball, R. and Brown, P. (1968) An Empirical Evaluation of Accounting Income Numbers. Journal of Accounting Research, 6, 159-178. http://dx.doi.org/10.2307/2490232

[24] Beaver, W.H. (1968) The Information Content of Annual Earnings Announcements-Empirical Research in Accounting, Selected Studies. Journal of Accounting Research, 6, 67-92. http://dx.doi.org/10.2307/2490070

[25] Beaver, W.H., Lambert, R. and Morse, D. (1980) The Information Content of Security Prices. Journal of Accounting and Economics, 2, 3-28. http://dx.doi.org/10.1016/0165-4101(80)90013-0

[26] Lev, B. (1989) On the Usefulness of Earnings and Earnings Research—Lessons and Directions from Two Decades of Empirical Research. Journal of Accounting Research, 27, 153-192. http://dx.doi.org/10.2307/2491070

[27] Hayn, C. (1995) The Information Content of Losses. Journal of Accounting and Economics, 20, 125-153. http://dx.doi.org/10.1016/0165-4101(95)00397-2

[28] Amir, E. and Lev, B. (1996) Value Relevance of Nonfinancial Information: The Wireless Communications Industry. Journal of Accounting and Economics, 22, 3-30. http://dx.doi.org/10.1016/S0165-4101(96)00430-2

[29] Collins, D.W., Maydew, E.L. and Weiss, I.S. (1997) Changes in the Value-Relevance of Earnings and Book Values over the Past Forty Years. Journal of Accounting and Economics, 24, 39-67. http://dx.doi.org/10.1016/S0165-4101(97)00015-3

[30] Ely, K. and Waymire, G. (1999) Accounting Standard-Setting Organizations and Earnings Relevance: Longitudinal Evidence from NYSE Common Stocks, 1927-93. Journal of Accounting Research, 37, 293-317. http://dx.doi.org/10.2307/2491411

[31] Lev, B. and Zarowin, P. (1999) The Boundaries of Financial Reporting and How to Extend Them. Journal of Accounting Research, 37, 353-385. http://dx.doi.org/10.2307/2491413

[32] Brown, S., Lo, K. and Lys, T. (1999) Use of $\mathrm{R}^{2}$ in Accounting Research: Measuring Changes in Value Relevance over the Last Four Decades. Journal of Accounting and Economics, 28, 83-115. http://dx.doi.org/10.1016/S0165-4101(99)00023-3

[33] Armstrong, C.S., Barth, M.E., Jagolinzer, A.D. and Riedl, E.J. (2007) Market Reaction to the Adoption of IFRS in Europe. http://www.hbs.edu/research/pdf/09-032.pdf

[34] Landsman, W.R., Maydew, E.L. and Thornock, J.R. (2009) The Information Content of Annual Earnings Announcements and Mandatory Adoption of IFRS. http://papers.ssrn.com/sol3/papers.cfm?abstract_id=1337567

[35] Bartov, E., Goldberg, S. and Kim, M. (2005) Comparative Value Relevance among German, U.S. and International Accounting Standards-A German Stock Market Perspective. Journal of Accounting, Auditing, \& Finance, 20, 95-119.

[36] Barth, M.E., Landsman, W.R., Lang, M. and Williams, C. (2009) Are International Accounting Standards-Based and US GAAP-Based Accounting Amounts Comparable? http://www.insead.edu/facultyresearch/areas/accounting/events/documents/Barth.Landsman.Lang.Williams.2011.pdf 
[37] Hung, M. and Subramanyam, K.R. (2004) Financial Statement Effects of Adopting International Accounting Standards: The Case of Germany. http://papers.ssrn.com/sol3/papers.cfm?abstract_id=622921

[38] Gassen, J. and Sellhorn, T. (2006) Applying IFRS in Germany-Determinants and Consequences. Betriebswirtschaftliche Forschung und Praxis, 58, 365-386.

[39] Schiebel, A. (2006) Value Relevance of German GAAP and IFRS Consolidated Financial Reporting: An Empirical Analysis on the Frankfurt Stock Exchange. http://papers.ssrn.com/sol3/papers.cfm?abstract_id=916103

[40] Debond, W.F.M. and Thaler, R. (1985) Does the Stock Market Overreact? Journal of Finance, 40, 793-805. http://dx.doi.org/10.1111/j.1540-6261.1985.tb05004.x

[41] Bernard, V.L. (1993) Stock Price Reactions to Earnings Announcements. In: Thaler, R., Ed., Advances in Behavioral Finance, Princeton University Press, New York, 157-183.

[42] Paulus, H. (1997) Style-Investing auf europaeischenAktienmaerkten. Eine empirische Analyse bewertungsrelevanter Fundamentalfaktoren. In: Steiner, M., Ed., Reihe: Portfoliomanagement-Band 6, Uhlenbruch, Bad Soden.

[43] Haugen, R.A. (1995) The New Finance: The Case against Efficient Markets. Prentice-Hall, Englewood Cliffs.

[44] Fama, E.F. and French, K.R. (1988) Permanent and Temporary Components of Stock Prices. Journal of Political Economy, 96, 246-272. http://dx.doi.org/10.1086/261535

[45] Poterba, J. and Summers, L. (1988) Mean Revision in Stock Prices: Evidence and Implications. Journal of Financial Economics, 22, 27-59. http://dx.doi.org/10.1016/0304-405X(88)90021-9

[46] Fama, E.F. and French, K.R. (1992) The Cross-Section of Expected Stock Returns. Journal of Finance, 47, 427-465. http://dx.doi.org/10.1111/j.1540-6261.1992.tb04398.x

[47] Banz, R.W. (1981) The Relationship between Return and Market Value of Common Stocks. Journal of Financial Economics, 9, 3-18. http://dx.doi.org/10.1016/0304-405X(81)90018-0

[48] Zass, M. and Schaefer, H.J. (1992) Portfeuillemanagement: Zweifel am “Beta-Faktor”. Sparkasse, 109, 391-392.

[49] Garz, H., Guenther, S. and Moriabadi, C. (2002) Portfoliomanagement-Theorie und Anwendung. Bankakademie-Verlag, Frankfurt.

[50] Spremann, K. (1992) Risk-Management-Serie-Ein Risikomass verliert seine Glaubwuerdigkeit. Publikation der Schweizer Bank, Zurich, 54-57.

[51] Basu, S. (1983) The Relationship between Earnings’ Yield, Market Value and Return for NYSE Common Stocks: Further Evidence. Journal of Financial Economics, 12, 129-156. http://dx.doi.org/10.1016/0304-405X(83)90031-4

[52] Moells, S.H. and Strauss, M. (2007) Bewertungsrelevanz der Rechnungslegunng—Stand und Implikationen der empirischen Forschung fuer Aktionaere und Regulierer. Zeitschrift fuer Betriebswirtschaft, 77, 955-995.

[53] Wagenhofer, A. and Ewert, R. (2002) Externe Unternehmensrechnung. Springer, Heidelberg.

[54] Lo, K. and Lys, T.Z. (2000) Bridging the Gap between Value Relevance and Information Content. http://papers.ssrn.com/sol3/papers.cfm?abstract_id=210948

[55] Beaver, W.H. (2002) Perspectives on Recent Capital Market Research. The Accounting Review, 77, 453-474. http://dx.doi.org/10.2308/accr.2002.77.2.453

[56] Fama, E.F. (1970) Efficient Capital Markets: A Review of Theory and Empirical Work. The Journal of Finance, 25, 383-417. http://dx.doi.org/10.2307/2325486

[57] Fama, E.F. (1991) Efficient Capital Markets II. Journal of Finance, 46, 1575-1617. http://dx.doi.org/10.1111/j.1540-6261.1991.tb04636.x

[58] Kothari, S.P. (2001) Capital Market Research in Accounting. Journal of Accounting and Economics, 31, $105-231$. http://dx.doi.org/10.1016/S0165-4101(01)00030-1

[59] Hoitash, R., Krishnan, M. and Sankaraguruswamy, S. (2002) Earnings Quality and Price Quality. http://papers.ssrn.com/sol3/papers.cfm?abstract_id=320831

[60] Barth, M.E. and Kallapur, S. (1996) The Effects of Cross-Sectional Scale Differences on Regression Results in Empirical Accounting Research. Contemporary Accounting Research, 13, 527-567. http://dx.doi.org/10.1111/j.1911-3846.1996.tb00514.x

[61] White, H. (1980) A Heteroskedasticity-Consistent Covariance Matrix Estimator and a Direct Test for Heteroskedasticity. Econometrica, 48, 817-838. http://dx.doi.org/10.2307/1912934

[62] Durbin, J. and Watson, G.S. (1950) Testing for Serial Correlation in Least-Squares Regression. Biometrika, 37, 409428.

[63] Hand, J.R.M. (2000) The Net Present Value and Returns-to-Scale of Intangibles in the New Economy. Working Paper, University of North Carolina, Chapel Hill. 
[64] Easton, P.D. and Sommers, G.A. (2003) Scale and Scale Effects in Market Based Accounting Research. Journal of Business Finance \& Accounting, 30, 25-56. http://dx.doi.org/10.1111/1468-5957.00482

[65] Kothari, S.P. and Zimmerman, J. (1995) Price and Return Models. Journal of Accounting and Economics, 20, $155-192$. http://dx.doi.org/10.1016/0165-4101(95)00399-4

[66] Trautwein, A. (2007) Wertrelevanz von Patentinformationen im Kontext der Rechnungslegung-Eine empirische Betrachtung fuerboersenorientierte Kapitalgesellschaften in Deutschland. GWV, Wiesbaden.

[67] Granger, C.W.J. and Newbold, P. (1974) Spurious Regressions in Econometrics. Journal of Econometrics, 2, 111-120. http://dx.doi.org/10.1016/0304-4076(74)90034-7

[68] Easton, P.D. (1998) Discussion of Revalued Financial, Tangible, and Intangible Assets: Association with Share Prices and Non-Market-Based Value Estimates. Journal of Accounting Research, 36, 235-247.

[69] Phillips, P.C.B. (1986) Understanding Spurious Regressions in Econometrics. Journal of Econometrics, 33, 311-340. http://dx.doi.org/10.1016/0304-4076(86)90001-1

[70] Barth, M.E. (2000) Valuation-Based Accounting Research: Implications for Financial Reporting and Opportunities for Future Research. Accounting and Finance, 40, 7-31. http://dx.doi.org/10.1111/1467-629X.00033

[71] Ota, K. (2001) The Impact of Valuation Models on Value-Relevance Studies in Accounting: A Review of Theory and Evidence. http://papers.ssrn.com/sol3/papers.cfm?abstract id=280873

[72] Ryan, S.G. and Zarowin, P.A. (1995) On the Ability of the Classical Errors in Variables Approach to Explain Earnings Response Coefficients and R2s in Alternative Valuation Models. Journal of Accounting, Auditing and Finance, 10, 767-786.

[73] Warfield, T.D. and Wild, J.J. (1992) Accounting Recognition and the Relevance of Earnings as an Explanatory Variable for Returns. The Accounting Review, 67, 821-842.

[74] Easton, P.D., Harris, T.S. and Ohlson, J.A. (1992) Aggregate Accounting Earnings Can Explain Most of Security Returns. Journal of Accounting and Economics, 15, 119-142. http://dx.doi.org/10.1016/0165-4101(92)90015-T

[75] Basu, S. (1997) The Conservatism Principle and the Asymmetric Timeliness of Earnings. Journal of Accounting and Economics, 24, 3-37. http://dx.doi.org/10.1016/S0165-4101(97)00014-1

[76] Jessen, U. and Haaker, A. (2011) Der IFRS for SMEs im Lichte der fachlich-zustimmenden und der politischablehnenden Auffassung. Der Betrieb, 64, M01.

[77] Schneider, D. (2000) Foerdern Internationale Rechnungslegungsstandards Wettbewerb als Verwertung von Wissen? Zfbf, 52, 23-40.

[78] Mansi, S.A., Maxwell, W.F. and Wald, J.K. (2009) Creditor Protection Laws and the Cost of Debt. Journal of Law and Economics, 52, 701-171. http://dx.doi.org/10.1086/605566

[79] Janssen, J. and Gronewold, U. (2010) IFRS for Small and Medium-Sized Entities, Konzeptionelle Schwaechen des neuen Standards und ihre Implikationen. Internationale und kapitalmarktorientierte Rechnungslegung, 10, 75-80.

[80] Kirsch, H. (2010) IFRS for SMEs: Positionierung der IFRS-Rechnungslegung fuer kleine und mittelgrosse Unternehmen im Verhaeltnis zu den full IFRS. Zeitschrift fuer Internationale Rechnungslegung, 5, 119-126.

[81] Schildbach, T. (2009) Rechnungslegung nach IFRS und ihre Beurteilung aus der Sicht der Anforderungen von KMU und Handwerksbetrieben. In: Hinterdobler, T. and Kuepper, H.U., Eds., Ausrichtung der Rechnungslegung fuer KMU und Handwerksbetriebe: Kriterien, Gestaltungsmoeglichkeiten und Grenzen ihrer Regulierung im europaeischen Kontext, German Crafts Institute, Munich, 33-76.

[82] Eierle, B. and Haller, A. (2010) IFRS for SMEs-Ergebnisse einer Befragung von nitch kapitalmarktorientierten Unternehmen in Deutschland. In: Eierle, B. and Haller, A., Eds., BDI, DRSC, Berlin, 1-32.

[83] IASB (2010) IFRS for SMEs Update, Issues 2010-1 to 2010-7. IASB.

[84] EU Commission (2010) Summary Report of the Responses Received to the Commission's Consultation on the International Financial Reporting Standard for Small and Medium-Sized Entities.

http://ec.europa.eu/internal_market/accounting/docs/ifrs/2010-05-31_ifrs_sme_consultation_summary_en.pdf

[85] Eierle, B. and Haller, A. (2010) IFRS for SMEs_Ergebnisse einer Befragung von nicht kapitalmarktorientierten Unternehmen in Deutschland. In: Eierle, B. and Haller, A., Eds., BDI, DRSC, Berlin, 1-44.

[86] http://www.2ask.de

[87] EU Commission (2006) Die neue KMU-Definition—Benutzerhandbuch und Mustererklaerung. http://ec.europa.eu/enterprise/policies/sme/files/sme definition/sme user guide de.pdf

[88] Ali, A. and Hwang, L.S. (2000) Country-Specific Factors Related to Financial Reporting and the Value Relevance of Accounting Data. Journal of Accounting Research, 38, 1-21. http://dx.doi.org/10.2307/2672920 
[89] Guenther, D.A. and Young, D. (2000) The Association between Financial Accounting Measures and Real Economic Activity: A Multinational Study. Journal of Accounting and Economics, 29, 53-72. http://dx.doi.org/10.1016/S0165-4101(00)00013-6

[90] Hennrichs, J. (2005) Bilanzgestuetzte Kapitalerhaltung, HGB-Jahresabschluss und Massgeblichkeitsprinzip—Dinosaurier der Rechtsgeschichte? Steuer und Wirtschaft, 256-264.

[91] Huettemann, R. (2004) BB-Gesetzgebungsreport: Internationalisierung des deutschen Handelsbilanzrechts im Entwurf des Bilanzrechtsreformgesetzes. Betriebs-Berater, 203-209.

[92] Kleindiek, D. (2006) Krisenvermeidung in der GmbH: Gesetzliches Mindestkapital, Kapitalschutz und Eigenkapitalersatz. Zeitschrift fur Unternehmens- und Gesellschaftsrecht, 35, 335-365.

[93] Kahle, H. and Dahlke, A. (2007) IFRS fuermittelstaendische Unternehmen? Deutsches Steuerrecht, 45, 313-318.

[94] Prinz, U. (2003) Reform der deutschen Rechnungslegung-Gedanken und Anregungen an den Gesetzgeber zur Umsetzung der Mitgliedsstaatenwahlrechte der IAS/IFRS-Verordnung aus Praktikersicht. Deutsches Steuerrecht, 41, 13591364.

[95] Schoen, W. (2001) Internationalisierung der Rechnungslegung und Glaeubigerschutz. Die Wirtschaftspruefung, 54, 74-79.

[96] Schulze-Osterloh, J. (2003) Internationale Rechnungslegung fuer den Einzelabschluss und fuer Unternehmen, die den oeffentlichen Kapitalmarkt nicht in Anspruch nehmen. Zur Ausuebung des Mitgliedstaatenwahlrechts nach Art 5 der IAS-Verordnung. Zeitschrift fuer Wirtschaftsrecht, 93-101. 


\section{Appendix}

Table A2. Information quality under German-GAAP and (full-)IFRS from the perspective of non-publicly traded mid-sized corporations.

\begin{tabular}{|c|c|c|c|c|c|c|c|c|c|}
\hline \multirow{3}{*}{ 1) } & \multicolumn{8}{|c|}{ Publicly traded? } & \multirow{3}{*}{ Sig. } \\
\hline & \multicolumn{4}{|c|}{ Yes } & \multicolumn{4}{|c|}{ No } & \\
\hline & $\overline{\mathbf{x}}_{\text {arithm }}$ & $\delta_{\mathrm{x}}$ & $\mathbf{N}$ & $\%$ & $\overline{\mathbf{x}}_{\text {arithm }}$ & $\delta_{\mathrm{x}}$ & $\mathbf{N}$ & $\%$ & \\
\hline a) Corporate management & & & 67 & & & & 427 & & \\
\hline - German-GAAP & & & 20 & 29.85 & & & 142 & 33.26 & \\
\hline - pendant & 3.87 & 1.48 & 31 & 46.27 & 3.46 & 1.37 & 237 & 55.50 & 0.03 \\
\hline - (full-)IFRS & & & 16 & 23.88 & & & 48 & 11.24 & \\
\hline b) Dividend assessment & & & 68 & & & & 427 & & \\
\hline - German-GAAP & & & 27 & 39.71 & & & 155 & 36.30 & \\
\hline - Pendant & 3.29 & 1.36 & 35 & 51.47 & 3.33 & 1.33 & 235 & 55.04 & 0.85 \\
\hline - (full-)IFRS & & & 6 & 8.82 & & & 37 & 8.67 & \\
\hline c) Decision usefulness & & & 67 & & & & 424 & & \\
\hline - German-GAAP & & & 14 & 20.90 & & & 116 & 27.36 & \\
\hline - pendant & 4.01 & 1.32 & 36 & 53.73 & 3.71 & 1.20 & 247 & 58.25 & 0.06 \\
\hline - (full-)IFRS & & & 17 & 25.37 & & & 61 & 14.39 & \\
\hline
\end{tabular}

This table presents survey data regarding the question, which accounting standard is more qualified for the fulfillment of the 3 quality criteria identified (a) Corporate management; b) Dividend assessment; c) Decision usefulness), German-GAAP or IFRS? A seven-tier Likert-scale was used with $\{1\}$ "German-GAAP much better" via $\{2\}$ and $\{3\}$ to " $\{4\}$ pendant" and via $\{5\}$ and $\{6\}$ to $\{7\}$ "IFRS much better". Furthermore, it was possible to use the field "not specified", which led to a maximum of 495 answers.

Table A3. Information quality under (full-)IFRS and IFRS for SME from the perspective of non-publicly traded mid-sized corporations.

\begin{tabular}{|c|c|c|c|c|c|c|c|c|c|}
\hline \multirow{3}{*}{ 2) } & \multicolumn{8}{|c|}{ Publicly traded? } & \multirow{3}{*}{ Sig. } \\
\hline & \multicolumn{4}{|c|}{ Yes } & \multicolumn{4}{|c|}{ No } & \\
\hline & $\overline{\mathbf{x}}_{\text {arithm }}$ & $\delta_{\mathrm{x}}$ & $\mathbf{N}$ & $\%$ & $\overline{\mathbf{x}}_{\text {arithm }}$ & $\delta_{\mathrm{x}}$ & $\mathbf{N}$ & $\%$ & \\
\hline a) Corporate management & & & 30 & & & & 199 & & \\
\hline - IFRS for SME & & & 9 & 30.00 & & & 48 & 24.12 & \\
\hline - pendant & 3.33 & 1.35 & 19 & 63.33 & 3.67 & 0.95 & 139 & 69.85 & 0.09 \\
\hline - (full-)IFRS & & & 2 & 6.67 & & & 12 & 6.03 & \\
\hline b) Dividend assessment & & & 28 & & & & 199 & & \\
\hline - IFRS for SME & & & 6 & 21.43 & & & 37 & 18.59 & \\
\hline - Pendant & 3.61 & 1.07 & 21 & 75.00 & 3.74 & 0.84 & 152 & 76.38 & 0.46 \\
\hline - (full-)IFRS & & & 1 & 3.57 & & & 10 & 5.03 & \\
\hline c) Decision usefulness & & & 30 & & & & 197 & & \\
\hline - IFRS for SME & & & 7 & 23.33 & & & 39 & 19.80 & \\
\hline - pendant & 3.67 & 1.32 & 20 & 66.67 & 3.74 & 0.88 & 147 & 74.62 & 0.71 \\
\hline - (full-)IFRS & & & 3 & 10.00 & & & 11 & 5.58 & \\
\hline
\end{tabular}

This table presents survey data concerning the question, regarding which of the 3 quality criteria identified (a) Corporate management; b) Dividend assessment; c) Decision usefulness) IFRS for SME will lead to improvements compared to the (full-)IFRS? A seven-tier Likert-scale was used with $\{1\}$ "IFRS for SME much better" via $\{2\}$ and $\{3\}$ to " $\{4\}$ pendant" and via $\{5\}$ and $\{6\}$ to $\{7\}$ "(full-)IFRS much better”. Furthermore, it was possible to use the field "not specified", which led to a maximum of 229 answers. 